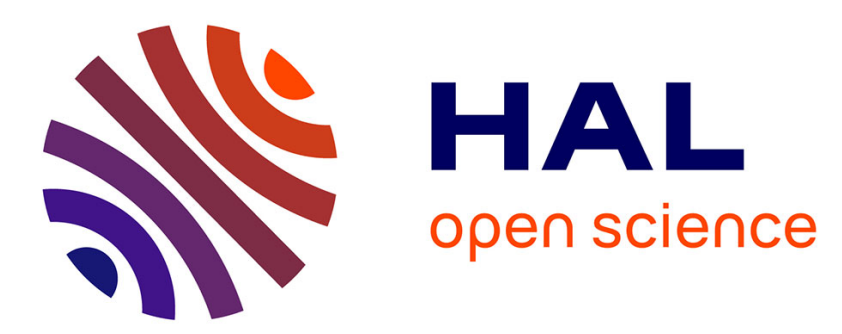

\title{
How the insect pathogen bacteria Bacillus thuringiensis and Xenorhabdus/Photorhabdus occupy their hosts
}

Christina C. Nielsen-Leroux, Sophie S. Gaudriault, Nalini N. Rama Rao, Didier D. Lereclus, Alain Givaudan

\section{- To cite this version:}

Christina C. Nielsen-Leroux, Sophie S. Gaudriault, Nalini N. Rama Rao, Didier D. Lereclus, Alain Givaudan. How the insect pathogen bacteria Bacillus thuringiensis and Xenorhabdus/Photorhabdus occupy their hosts. Current Opinion in Microbiology, 2012, 15 (3), pp.220 - 231. 10.1016/j.mib.2012.04.006 . hal-01004177

\section{HAL Id: hal-01004177 https://hal.science/hal-01004177}

Submitted on 29 May 2020

HAL is a multi-disciplinary open access archive for the deposit and dissemination of scientific research documents, whether they are published or not. The documents may come from teaching and research institutions in France or abroad, or from public or private research centers.
L'archive ouverte pluridisciplinaire HAL, est destinée au dépôt et à la diffusion de documents scientifiques de niveau recherche, publiés ou non, émanant des établissements d'enseignement et de recherche français ou étrangers, des laboratoires publics ou privés. 


\section{How the insect pathogen bacteria Bacillus thuringiensis and Xenorhabdus/Photorhabdus occupy their hosts Christina Nielsen-LeRoux ${ }^{1}$, Sophie Gaudriault ${ }^{2,3}$, Nalini Ramarao ${ }^{1}$, Didier Lereclus ${ }^{1}$ and Alain Givaudan ${ }^{2,3}$}

Insects are the largest group of animals on earth. Like mammals, virus, fungi, bacteria and parasites infect them. Several tissue barriers and defense mechanisms are common for vertebrates and invertebrates. Therefore some insects, notably the fly Drosophila and the caterpillar Galleria mellonella, have been used as models to study host-pathogen interactions for several insect and mammal pathogens. They are excellent tools to identify pathogen determinants and host tissue cell responses. We focus here on the comparison of effectors used by two different groups of bacterial insect pathogens to accomplish the infection process in their lepidopteran larval host: Bacillus thuringiensis and the nematode-associated bacteria, Photorhabdus and Xenorhabdus. The comparison reveals similarities in function and expression profiles for some genes, which suggest that such factors are conserved during evolution in order to attack the tissue encountered during the infection process.

\footnotetext{
Addresses

${ }^{1}$ INRA, UMR1319, Micalis, Génétique microbienne et Environnement, La Minière, F-78280 Guyancourt, France

${ }^{2}$ INRA, UMR 1333 Laboratoire DGIMI, F-34000 Montpellier, France

${ }^{3}$ Université Montpellier 2, UMR 1333 Laboratoire DGIMI, F-34000

Montpellier, France
}

Corresponding author: Nielsen-LeRoux, Christina (christina.nielsen@jouy.inra.fr)

\author{
Current Opinion in Microbiology 2012, 15:1-12 \\ This review comes from a themed issue on \\ Ecology \\ Edited by Bruno Lemaitre
}

1369-5274/\$ - see front matter

(C) 2012 Elsevier Ltd. All rights reserved.

http://dx.doi.org/10.1016/j.mib.2012.04.006

\section{Introduction}

Several entomopathogenic bacteria are known $\left[1^{\bullet}, 2^{\bullet}\right]$ but the most studied are Bacillus thuringiensis, Photorhabdus and Xenorhabdus. B. thuringiensis is a Gram-positive sporeforming bacterium that has been used for more than 50 years as bio-insecticide against insect pests in crop and forestry [3,4]. B. thuringiensis is closely related to Bacillus anthracis, the etiological agent of anthrax, and to Bacillus cereus, an opportunistic human pathogen causing foodborne gastroenteritis [5]. Photorhabdus and Xenorhabdus species include Gram-negative symbiotic bacteria associated with entomopathogenic nematodes also used as alternatives to pesticides to control numerous insect pests [6].

Most studies have focused on the specific insecticidal toxins produced by these bacteria (Cry and Cyt toxins for B. thuringiensis $[3,7]$ and Tc toxins for Photorhabdus and Xenorhabdus [8]). The role of other virulence and adaptation factors has been less investigated. Here, we highlight what is actually known about the factors necessary to cope with host tissue and host defence mechanisms. We aim to point out common infection strategies used by these bacteria. The issue is also to show that insect models, larger than Drosophila [9], mainly lepidopteran larvae can also be useful to improve the understanding of bacterial infection processes $\left[10^{\bullet \bullet}, 11^{\bullet}, 12^{\bullet \bullet}\right]$.

\section{Infection process}

A bacterial pathogen must be able to colonize its host by coping with different mechanical and physical barriers as well as cellular and humoral defence mechanisms (see Box 1). In nature, $B$. thuringiensis spores or vegetative cells, are taken up by the larva by ingestion or more accidentally by wounding through the cuticle (see Figure 1 for a description of $B$. thuringiensis-insect interaction). By contrast, natural infection involving Photorhabdus/Xenorhabdus mainly starts from the body cavity, since they are released at that site from the nematode hosts (see Figure 1 for a description of Photorhabdus/ Xenorhabdus infection process). Then, the two groups of bacteria discussed here will deal with the various larval compartments/tissues at different moments post infection. Therefore, we describe, in the following sections, the expression and effects of various bacterial factors, at different stages of the infectious process.

\section{Gut adaptation and intestinal barrier degradation}

Photorhabdus and Xenorhabdus are vectored by the nematode through the gut barrier and get direct access to the hemocoel. However, the two bacteria have orally active insecticidal toxins (see Box 2). For B. thuringiensis, the oral infection is the norm and success to breach the gut barrier is mainly depending on the action of Cry toxins, which both permit $B$. thuringiensis spores to germinate and also to weaken the midgut cells. However the relative importance of Cry toxins and the bacteria itself depends on the insect species [13] (see Figure 1 and Box 2 for details). In 


\section{Ecology}

\section{Box 1 Larval anatomy and basic defense.}

The lepidopteran larvae commonly used for infection analysis are Galleria mellonella, Spodoptera littoralis and Manduca sexta. The first insect barrier to overcome from the environment is the cuticle (skin), next the digestive tract, which is composed of a mouth, a proventricule, a forgut, a midgut and a hindgut. A sort of protective chitin rich web called peritrophic matrix, which separates the insect midgut from direct contact to food and pathogens [64], covers a large part of this 'tube' (see also Figure 1). The digestive tube is surrounded by the hemocoel (larval body cavity), which is mainly composed of hemolymph (blood). In the hemocoel are located fat body cells (liver function), circulating hemocytes and humoral immune factors. Hemocytes are key elements in cellular immune responses, which include phagocytosis, nodulation and encapsulation. Humoral factors include, among others, antimicrobial peptides, lysozyme, clothing mechanisms and prophenoloxidase, which are involved in the melanization process [65]. Antimicrobial peptides and lysozyme can also be found in the gut. Thus, if an infection by $B$. thuringiensis results in generalized septicaemia, it indicates that the bacteria have been capable to survive and develop inside the digestive tube, notably by competing with natural gut flora, and had won access to the insect hemocoel by degrading of the peritrophic matrix and midgut cells. Survival and development in the hemocoel of $B$. thuringiensis, Photorhabdus and Xenorhabdus indicate that these bacteria produce factors, which can cope with the above mentioned cellular and humoral immune effectors.

the gut, the newly germinated vegetative bacteria need to compete with the commensal gut microbiota and to resist to host factors like antimicrobial peptides in order to persist in the larval gut lumen. The factors involved in these resistance mechanisms are surface properties like the lysozyme, resistant peptidoglycan structure of $B$. thuringiensis and the production of bacteriocins [14], which can also explain the reduction of the gut microbiota predominantly composed of Enterococcus sp. in lepidopteran larvae [15].

Beside the plasmid-encoded Cry toxins (see Box 2), the $B$. thuringiensis genome contains many genes, which might take part in gut pathogenesis. The role of the PlcR regulon in virulence of $B$. thuringiensis and $B$. cereus was demonstrated by using $G$. mellonella larvae [16]. Indeed, deletion of the global transcriptional activator, $p l c R$, drastically reduces bacterial virulence in orally infected insects, but not by injecting the bacteria into the larval hemocoel [16,17], indicating that the PlcR regulon plays a key role in pathogenicity in the early stage of infection by oral route. PlcR controls the expression of 45 genes encoding secreted virulence factors including the pore forming enterotoxins complexes (Hbl and Nhe), hemolysins known for cytotoxic and hemolytic activities, antimicrobial peptides, and various degradative enzymes, which might allow the bacteria to develop in the intestinal environment and to damage the intestinal barrier [18]. Histological analyses indicate that $B$. thuringiensis colonize and damage the gut epithelium resulting in rupture of the gut integrity and the crossing of the gut barrier. Interestingly, a plcR mutant is blocked at the gut epithelial and transcriptional $g f p$ promoter
Box 2 Orally active insecticidal toxins and degradation of gut barriers, what else?

The $B$. thuringiensis-based insecticidal products are a mixture of spores and insecticidal toxins forming a crystal inclusion. These toxins, Cry (also called delta endotoxins) and Cyt proteins, are often encoded by plasmid carried genes. They are active against larval stages of many insect orders and other invertebrates like nematodes [66]. The mode of action of Cry toxin has been extensively studied for many insect species. The general procedure is shown in Figure 1 insert and several families of specific midgut receptors have been identified [67]. Meanwhile other indirect roles of Cry toxins: like the binding to the peritrophic matrix [68] or the possible interaction with the commensal gut microbiota in some insects [69] need more attention. Cyt toxins are present in a lower number of strains than Cry toxins and they are less specific as they interferes with several classes of cells including mammals. In many insects, the Cry toxin alone can kill the insect larvae (used in transgenic crops expression the Cry toxins) while for others the presence of the bacteria is needed [70]. Genes encoding Vip toxins (vegetative insecticidal proteins) have been found in various $B$. thuringiensis strains, but the expression and mode of action have been poorly studied (see (http:// www.lifesci.sussex.ac.uk/Home/Neil_Crickmore/Bt/) website for updated number of toxins). Although the main role of these toxins are related to gut cell interactions in the living insect, an eventual role during expression in the insect cadaver cannot be excluded.

Although Xenorhabdus and Photorhabdus directly enter within hemocoel following the release by nematode hosts, these bacteria, like $B$. thuringiensis, have oral insecticidal toxins (such as the 'toxin complexes' (Tc) and the 'Photorhabdus insect-related' (Pir) toxins) triggering massive damage to the gut epithelium of insect [8]. Despite intensive research on insecticidal toxin family, their reliable involvement in a precise step of the life cycle of the bacterial symbionts remained enigmatic. Indeed, $P$. luminescens Tc toxins inhibit phagocytosis of bacteria when added on insect hemocyte monolayers and recently, the biologically active components of the Tc toxins have been characterized as ADP-ribosyltransferases, which modify actin and Rho GTPases [71]. Because Tc toxins have also insecticidal activities after injection into insects, it is likely that the Tcdependent inhibition of phagocytosis takes place in the hemolymph during bacterial infection. More surprisingly is the discovery of oral insecticidal activity of the universally occurring chaperon molecule GroEL in X. nematophila. GroEL protein has no effect when injected into the hemocoel or when added to cultures of insect hemocytes [72]. It is noteworthy that the XnGroEL protein and the insecticidal Tc-like complexes of the insect pathogen, Yersinia entomophaga, have chitin binding and chitinase activities, respectively. Busby et al. (2011) [73] propose that chitinase proteins form an integral part of the Tc complexes in Photorhabdus and Xenorhabdus as well. It is tempting to speculate that chitinase activity acting on the peritrophic membrane may help toxins or bacteria to reach gut epithelial cells. According to the biology of nematode symbionts, we can also propose that chitinase associated toxins may be also required in late infection in the cadaver compartment by contributing to the degradation of the insect cadaver exoskeleton. Moreover, Tc-like encoding genes have been recently found in some $B$. thuringiensis strains indicating a conserved and probably important function of these toxins, which would merit further attention in the $B$. thuringiensis life cycle [74].

fusions showed that PlcR-regulated factors are expressed in the insect gut (Nielsen-LeRoux, unpublished data). However, deletion of enterotoxin genes (Nhe, Hbl complexes and CytK) did not significantly alter the insecticidal properties of $B$. thuringiensis towards three lepidopteran insects [19]. Then, further studies are 


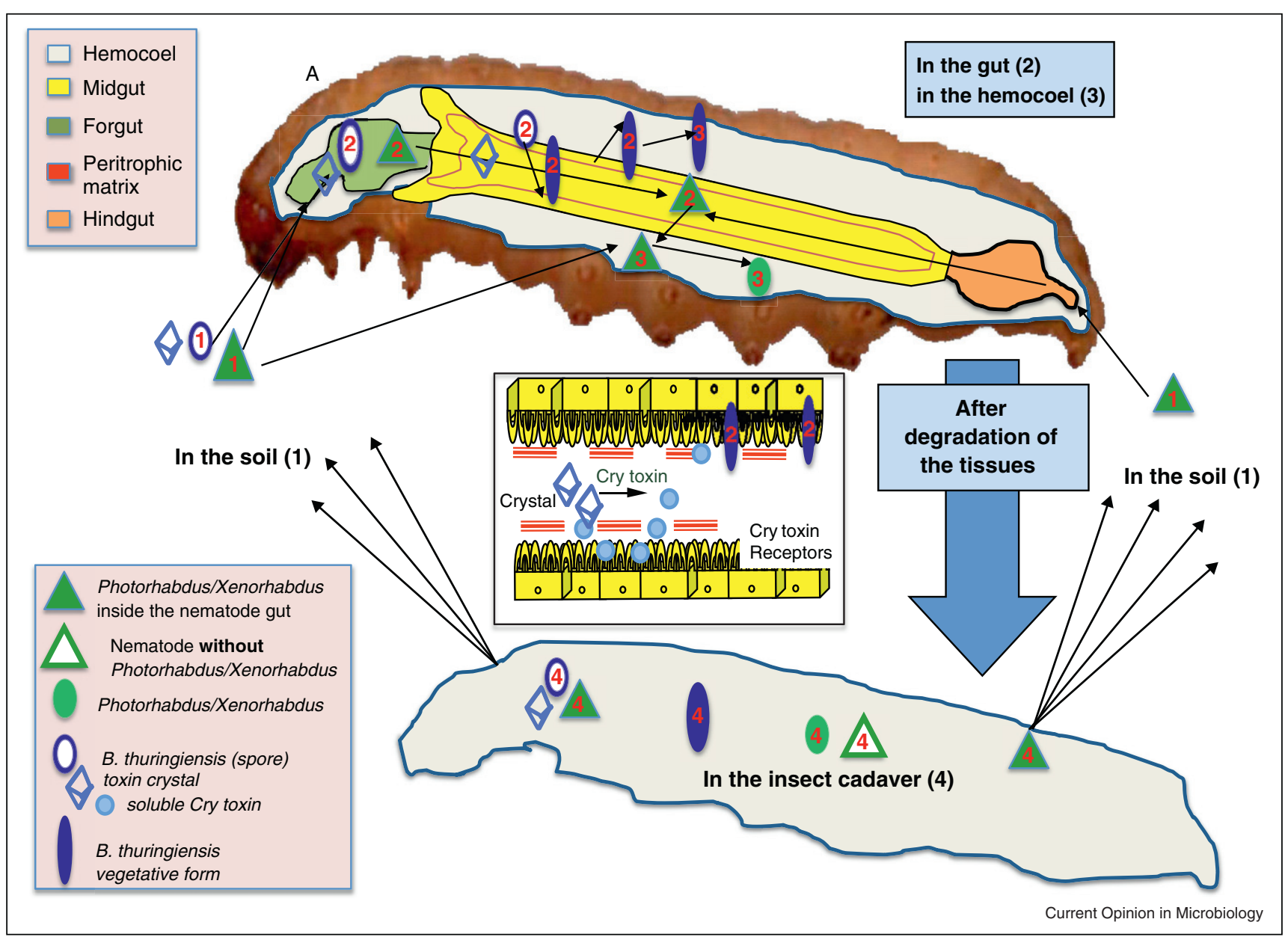

General natural larval infection and life cycles of B. thuringiensis, Photorhabdus and Xenorhabdus. B. thuringiensis is primary an oral pathogen and the spores along with the crystal toxin are acting together to kill the insect. When ingested by a susceptible insect, the crystal inclusions are solubilized in the gut and protoxins are activated by digestive enzymes (steps 1, 2, and insert). The activated toxins (small blue circles) are then able to cross the peritrophic barrier and to bind different classes of midgut receptors (Box 2, insert and [7]). This results in the formation of pores in the epithelial midgut cells and impairment of intestinal function. This creates favorable conditions for spore-germination and development of vegetative growth (steps 2 and 3). Bacteria multiply and produce various virulence factors allowing access to the hemocoel [58]. They adapt to this new compartment and produce new virulence factors to combat the host defenses (step 3). This may allow the bacteria to cause septicemia, resulting in insect death (step 4). Within the host cadaver the B. thuringiensis cells have to cope with novel growth conditions to complete their development, ending with the production of resistant spores and Cry toxin crystals able to disseminate in the environment to start a new cycle of infection in another host. Xenorhabdus and Photorhabdus spp. are pathogens of numerous insects and are mutualists of nematodes from the family Heterorhabditidae and Steinernematidae, respectively. The life cycle of Photorhabdus and Xenorhabdus begins and ends with the colonization of the intestinal tract of nonfeeding stage of the nematode known as the infective juvenile (IJ) [51]. Actually, the IJ stage nematodes generally use natural openings of insect larvae (mouth and anus) as main routes of entry (step 1), and end up in digestive track (gut; step 2) before entering in the hemocoel (step 3). However, the nematode vector of Photorhabdus, Heterorhabditis, can also enter into host's body by puncturing the larval cuticle (for review see [62]). Within the hemocoel, nematodes release their bacterial symbionts that undergo insect infection (step 3). In the insect cadaver, occur bacterial multiplication and nematode reproduction (step 4). During this life cycle, Photorhabdus and Xenorhabdus must successfully accomplish three distinct roles within the insect host: (i) overcome insect immune response, and kill insects, (ii) produce nutrients from the insect cadaver to facilitate development of the nematode, and (iii) colonize the IJ stage of the nematode [63]. After rounds of nematode reproduction, progeny nematodes receive uncharacterized environmental cues that stimulate the development of a new generation of IJs colonized by the bacteria before emerging of several hundred thousand IJs from an insect cadaver.

needed to show the precise role of the PlcR-regulated factors in insect gut infection, like searched by a RTPCR analysis [20]. In addition, to understand exactly how the bacteria cross the gut, including the peritrophic matrix (see Box 1), it is important to fully elucidate the relative impact of Cry toxins and the other B. thuringiensis bacterial factors, (like the metalloprotease Enhancin [21]), on these barriers. 


\section{Inside the hemocoel}

Entomopathogenic bacteria entering in the hemolymph compartment have to face the insect immune system consisting of several defensive mechanisms that parallel many aspects of the vertebrate innate immune system (see Box 1).

\section{Facing the humoral immunity}

As part of the humoral response, insects produce a range of AMPs that target bacterial envelope components [22]. $P$. luminescens and $B$. thuringiensis counteract the humoral AMP response through constitutive modifications of their surface properties. In Salmonella, the addition of 4-aminoarabinose moieties on the negatively charged lipopolysaccharides LPS, requires the products of the two component system PhoPQ-regulated pmrHFIJKLM operon [23,24]. In P. luminescens, mutation of either phoP or the $p m r K$ homologue, $p b g E 1$, resulted in both an increased sensitivity to cationic AMPs and decreased virulence towards insects $[25,26]$. The $d l t$ operon encodes proteins that alanylate the teichoic acids on the surface of Gram-positive bacteria, which neutralizes their negative charge and thus prevent attack by cationic AMPs. In $B$. cereus, and $B$. thuringiensis, a dlt null mutant is sensitive to molecules from the insect humoral immune system such as lysozyme, and the cationic AMP, cecropin, from the Fall Armyworm, Spodoptera frugiperda and shows reduced virulence towards lepidopteran insects $\left[27^{\bullet}\right]$. The strategy used by $X$. nematophila to counteract cationic AMPs is to prevent their production: cecropin transcript levels are induced after injection of non-pathogenic Salmonella enterica, but not after injection of $X$. nematophila $[28,29]$. This suppression effect is under the control of the global regulators Lrp and CpxR [30*], but the effectors responsible for the interference have yet to be identified. Many entomopathogenic bacteria secrete proteases that degrade antimicrobial peptides. The role of the B. thuringiensis metalloprotease InhA1 in inhibition of AMP activity and full virulence following injection into the hemocoel have been reported [31]. Likewise, the Photorhabdus metalloprotease PrtA destroys commercial cecropins A and B and inhibits insect antibacterial activity when inoculated within lepidoptera [32]. Therefore, both $P$. luminescens and $B$. thuringiensis/B. cereus are recognized by the insect immune system but overcome it by counteracting the action of antimicrobial peptides by multiple ways.

\section{Facing the cellular immunity}

Photorhabdus, Xenorhabdus and B. thuringiensis also interfere with insect cellular immunity. The cellular response is mediated by circulating hemocytes and includes both phagocytosis and nodulation (see Box 1). The latter response involves the aggregation of hemocytes around the invading microorganisms. Photorhabdus, Xenorhabdus and $B$. thuringiensis produce an array of cytolysins/hemolysins and toxins, some of which have been shown to induce necrosis or apoptosis when added to cultures of insect-immune cells (see Table 1). P. luminescens has a type III secretion system (TTSS) required for resistance to phagocytosis and encapsulation in nodules. This locus encodes an effector molecule (LopT), which is a GTPasemodifying cytotoxin. Interestingly, the expression of the lopT gene coincides with the T3SS-dependent inhibition of phagocytosis in the course of insect infection, indicating a possible role for Lop'T to prevent uptake of $P$. luminescens by hemocytes [33]. By contrast, the genomes of Xenorhabdus nematophila and Xenorhabdus bovienii do not encode homologues of a dedicated TTSS [34]. Nevertheless, the $X$. nematophila flagellar secretion system (flagellar TTSS) is necessary for secretion of at least one non-flagellar protein, a lipase [35-37]. In addition, the flagellar regulator, FliZ, controls the expression of the $\mathrm{XaxAB}$ and XhlAB hemolysins encoding-genes [36]. $\mathrm{XaxAB}$ is the prototype of a new family of hemolysins with apoptotic and pore-forming activities in mammalian and invertebrate cells [38]. The second FliZ-dependent hemolysin, XhlA, is a cell surface-associated hemolysin belonging to the two-partner secretion system family [39]. While XhlA and XaxAB recombinant proteins mediated lysis of insect immune cells [38,39], only XhlA has been shown to be required for the full virulence of $X$. nematophila in lepidoptera. B. thuringiensis also produces an hemolysin, HlyII, which is a pore forming toxin able to induce lysis of mouse macrophages and insect hemocytes by apoptosis [40]. A protein (CwpFM) with homology to cell wall peptidases in several bacteria, notably B. subtilis, was shown to be important for full virulence in Galleria, and to induce macrophage vacuolization. However its precise role during insect infection still remains to be elucidated [41]. InhA1, is a metalloprotease localized in the Bacillus exosporium, and allows $B$. thuringiensis spores to escape from murine macrophages [42]. A similar role in the insect cells still needs investigations. Thus, these factors allow $B$. thuringiensis to counteract the bactericidal properties of host phagocytic cells. As for Photorhabdus and Xenorhabdus, a mutation in the flagellar apparatus of $B$. thuringiensis has a pleiotropic effect. Indeed, the deletion of FlhA flagellar body protein resulted in decrease in virulence following both oral and hemocoel infection, probably owing to the combined effect of reduced cell adherence and less secreted virulence factors [43].

\section{Competing with the host for iron}

Another part of innate host response to infection is the sequestering of iron sources to limit bacterial growth [44]. Several factors involved in iron acquisition contribute to the virulence of $B$. thuringiensis and Photorhabdus (see Table 1). The recently identified surface protein of $B$. thuringiensis, IlsA [12 ${ }^{\bullet \bullet}$, is involved in iron uptake from ferritin and heme. An IVET system and $g f p$ transcriptional fusions showed that the ilsA gene is specifically transcribed when bacteria are within the hemocoel and the ils A mutant is affected in its virulence towards Galleria 
Table 1

B. thuringiensis, Photorhabdus and Xenorhabdus effectors influencing the infection process in lepidopteran larvae

\begin{tabular}{|c|c|c|c|c|c|c|c|}
\hline \multirow[t]{2}{*}{ Bacteria } & \multicolumn{2}{|r|}{ Class of effectors } & \multirow{2}{*}{$\begin{array}{l}\text { Mutant } \\
\text { virulence }^{a}\end{array}$} & \multicolumn{3}{|c|}{ Potential site(s) of effect and/or target(s) in the insect ${ }^{b}$} & \multirow[t]{2}{*}{ References } \\
\hline & Name & Short function/role & & Gut & Hemocoel & Cadaver & \\
\hline \multicolumn{8}{|l|}{ Regulators } \\
\hline \multirow[t]{3}{*}{ B. thuringiensis } & PlcR & $\begin{array}{l}\text { Quorum-sensing pleiotropic regulator, } \\
\text { early phase of infection }\end{array}$ & $\begin{array}{l}\text { I: VIR } \\
\text { O: NON-VIR }\end{array}$ & $\begin{array}{l}\text { Activates the expression } \\
\text { of } 45 \text { genes, intestinal } \\
\text { cell cytotoxicity }\end{array}$ & & & {$[16,18]$} \\
\hline & NprR & Quorum-sensing pleiotropic regulator & $\begin{array}{l}\text { I: VIR } \\
\text { O: VIR }\end{array}$ & & & $\begin{array}{l}\text { Nutriment acquisition, } \\
\text { saprophytic } \\
\text { development }\end{array}$ & {$\left[48,49^{\bullet \bullet}\right]$} \\
\hline & Fur & Ferric uptake regulator & O: ATT & & $\begin{array}{l}\text { Regulates the expression of } \\
\text { genes involved in iron } \\
\text { uptake and virulence }\end{array}$ & & [46] \\
\hline \multirow[t]{4}{*}{ Photorhabdus } & PhoPQ & Two component system & I: NON-VIR & & AMP resistance & & [25] \\
\hline & LuxS & $\begin{array}{l}\text { Quorum-sensing auto-inducer } \\
2 \text { synthesis protein }\end{array}$ & I: ATT & & ROS resistance & & [75] \\
\hline & HcaR & LysR-type transcriptional regulator & I: ATT & & ROS resistance & & [76] \\
\hline & HexA & LysR homolog A regulator & I: ATT & & & & [77] \\
\hline \multirow[t]{4}{*}{ Xenorhabdus } & FlhD & Master regulon of the flagellar cascade & $\mathrm{I}: \mathrm{ATT}$ & & $\begin{array}{l}\text { Production of hemolysins, } \\
\text { motility }\end{array}$ & Production of lipases & [78] \\
\hline & LrhA & $\begin{array}{l}\text { LysR homolog A regulator, positive } \\
\text { activator of } f / h D\end{array}$ & I: ATT & & & $\begin{array}{l}\text { Production of lipases, } \\
\text { Tc-like toxins }\end{array}$ & [37] \\
\hline & Lrp & $\begin{array}{l}\text { Leucine-responsive regulatory protein, } \\
\text { positive activator of } \operatorname{Irh} A \text { and } f / h D\end{array}$ & I: ATT & & $\begin{array}{l}\text { Production of hemolysins, } \\
\text { motility }\end{array}$ & $\begin{array}{l}\text { Production of lipases } \\
\text { and antimicrobial } \\
\text { activities }\end{array}$ & [79] \\
\hline & CpxRA & $\begin{array}{l}\text { Signal transduction system, positive } \\
\text { activator of IrhA }\end{array}$ & I: ATT & & $\begin{array}{l}\text { Inhibition of hemolysin } \\
\text { production; AMP resistance } \\
\text { and nodules formation }\end{array}$ & $\begin{array}{l}\text { Production of lipases, } \\
\text { inhibition of protease } \\
\text { and antimicrobial } \\
\text { activity production }\end{array}$ & [80] \\
\hline \multicolumn{8}{|c|}{ Insecticidal toxins (effect of purified toxins and/or mutants) } \\
\hline \multirow[t]{2}{*}{ B. thuringiensis } & Cry & $\begin{array}{l}\text { Cristal insecticidal toxins, pore } \\
\text { forming toxins }\end{array}$ & $\begin{array}{l}\text { I: Vir } \\
\text { O: ATT/ } \\
\text { NON-VIR }\end{array}$ & $\begin{array}{l}\text { Degradation of insect } \\
\text { intestinal epithelial cells }\end{array}$ & & & [7] \\
\hline & Vip & $\begin{array}{l}\text { Vegetative Insecticidal Proteins, pore } \\
\text { forming toxins }\end{array}$ & O: ATT & $\begin{array}{l}\text { Degradation of insect } \\
\text { intestinal epithelial cells }\end{array}$ & & & [81] \\
\hline $\begin{array}{l}\text { Photorhabdus/ } \\
\text { Xenorhabdus }\end{array}$ & Tc/Xpt (whole complex) & $\begin{array}{l}\text { Insecticidal protein complex ( } \\
\text { proteins A, B, C) }\end{array}$ & & Oral toxicity of the PP & $\begin{array}{l}\text { Phagocytosis inhibition } \\
\text { effect of the PP on } \\
\text { insect hemocytes }\end{array}$ & & {$[71,82-84]$} \\
\hline \multirow[t]{3}{*}{ Photorhabdus } & TcA & $\begin{array}{l}\text { Tetrameric homoprotein forming a } \\
\text { pore and probably involved in TcC } \\
\text { translocation }\end{array}$ & & $\begin{array}{l}\text { After oral ingestion of the } \\
\text { PP, degradation of insect } \\
\text { intestinal epithelial cells }\end{array}$ & & $\begin{array}{l}\text { Degradation of } \\
\text { intestinal epithelial } \\
\text { cells; expressed } \\
\text { in the gut }\end{array}$ & {$\left[11^{\bullet}, 83\right]$} \\
\hline & PirAB & $\begin{array}{l}\text { Insecticidal toxin (Cry and juvenile } \\
\text { hormone esterase domains) }\end{array}$ & & Oral toxicity of the PP & & & {$[85,86]$} \\
\hline & Pit & Insecticidal toxin (Cry34 domain) & & & $\begin{array}{l}\text { Toxicity after hemocoel } \\
\text { injection }\end{array}$ & & [87] \\
\hline
\end{tabular}




\begin{tabular}{|c|c|c|c|c|c|c|c|}
\hline \multirow[t]{2}{*}{ Bacteria } & \multicolumn{2}{|r|}{ Class of effectors } & \multirow{2}{*}{$\begin{array}{l}\text { Mutant } \\
\text { virulence }^{a}\end{array}$} & \multicolumn{3}{|c|}{ Potential site(s) of effect and/or target(s) in the insect ${ }^{b}$} & \multirow[t]{2}{*}{ References } \\
\hline & Name & Short function/role & & Gut & Hemocoel & Cadaver & \\
\hline \multirow[t]{2}{*}{ Xenorhabdus } & GroEL & Molecular chaperone & & $\begin{array}{l}\text { Oral toxicity of the PP } \\
\text { Chitin binding activity }\end{array}$ & & & [72] \\
\hline & MrxA & Soluble monomeric pilin & & Oral toxicity of the PP & $\begin{array}{l}\text { Pore forming-toxin } \\
\text { activity of PP }\end{array}$ & & [88] \\
\hline \multicolumn{8}{|l|}{ Hemolysins } \\
\hline \multirow[t]{2}{*}{ B. thuringiensis } & $\mathrm{Hbl}$ & $\begin{array}{l}\text { Tripartite toxin composed of } \\
3 \text { proteins } B, L 1 \text { and } L 2 \text {. Pore } \\
\text { forming toxin. }\end{array}$ & O: VIR & $\begin{array}{l}\text { Hemolytic and cytotoxic } \\
\text { to epithelial (mammals) }\end{array}$ & & & {$[19,89]$} \\
\hline & Hlyll & Pore forming toxin, virulence factor & I: ATT & & $\begin{array}{l}\text { Induces apoptosis of insect } \\
\text { hemocytes, }\end{array}$ & & {$[40,90]$} \\
\hline $\begin{array}{l}\text { Photorhabdus/ } \\
\text { Xenorhabdus }\end{array}$ & PhIA/XhIA & $\begin{array}{l}\text { Hemolysin belonging to the } \\
\text { two-partner secretion (TPS) family }\end{array}$ & $\begin{array}{l}\text { I: VIR (Photo) } \\
\text { I: ATT (Xeno) }\end{array}$ & & $\begin{array}{l}\text { Hemolytic activity in low-iron } \\
\text { conditions (Photorhabdus) or } \\
\text { in high-iron conditions } \\
\text { (Xenorhabdus) }\end{array}$ & & {$\left[10^{\bullet}, 39,91\right]$} \\
\hline Xenorhabdus & ХaxAB & Binary cytotoxin & I: VIR & & $\begin{array}{l}\text { Necrotic and apoptotic } \\
\text { activities on insect } \\
\text { hemocytes }\end{array}$ & $\begin{array}{l}\text { Late expression } \\
\text { in cadaver }\end{array}$ & {$\left[10^{\bullet}, 38\right]$} \\
\hline \multicolumn{8}{|c|}{ Effectors interfering with eukaryotic signals } \\
\hline \multirow[t]{3}{*}{ B. thuringiensis } & SPS & $\begin{array}{l}\text { Involved with Glucose-6-phosphate } \\
\text { uptake }\end{array}$ & $\begin{array}{l}\text { I: VIR } \\
\text { O: VIR }\end{array}$ & $\begin{array}{l}\text { Specifically expressed } \\
\text { in the gut }\end{array}$ & & & [104] \\
\hline & IlsA & $\begin{array}{l}\text { Involved in iron acquisition from } \\
\text { heme and ferritin }\end{array}$ & $\begin{array}{l}\text { I: ATT } \\
\text { O: ATT }\end{array}$ & & $\begin{array}{l}\text { Specifically expressed in } \\
\text { the hemocoel, iron regulated }\end{array}$ & & {$\left[12^{\bullet \bullet}, 45^{\bullet \bullet}\right]$} \\
\hline & Yvrc & Iron dicitrate uptake & O: ATT & & & & [92] \\
\hline \multirow[t]{6}{*}{ Photorhabdus } & Cif & Cyclomodulin & I: VIR & & $\begin{array}{l}\text { PP triggers inhibition of } \\
\text { proliferation and apoptosis } \\
\text { in insect cell }\end{array}$ & & [93] \\
\hline & SctC & $\begin{array}{l}\text { Secretin of a type } 3 \text { secretion } \\
\text { system (TTSS) }\end{array}$ & I: VIR & & $\begin{array}{l}\text { Nodule formation and } \\
\text { phagocytosis by } \\
\text { macrophage cells }\end{array}$ & & [33] \\
\hline & LopT & $\begin{array}{l}\text { Effector of the type } 3 \text { secretion } \\
\text { system (TTSS) }\end{array}$ & I: VIR & & $\begin{array}{l}\text { PP triggers the release of } \\
\text { RhoA and Rac from insect } \\
\text { cell membrane }\end{array}$ & & [33] \\
\hline & Mcf & $\begin{array}{l}\text { Protein with BH3 domain, which } \\
\text { is sufficient to allow Escherichia coli } \\
\text { both to persist within and kill an insect } \\
\text { (makes the caterpillars floppy) }\end{array}$ & & $\begin{array}{l}\text { PP triggers apoptosis in } \\
\text { the midgut epithelium }\end{array}$ & $\begin{array}{l}\text { PP triggers apoptosis in } \\
\text { hemocytes and inhibition } \\
\text { of phagocytosis }\end{array}$ & & {$[94,95]$} \\
\hline & ExbD & $\begin{array}{l}\text { Component of the TonB complex } \\
\text { involved in uptake of siderophores }\end{array}$ & $\mathrm{I}: \mathrm{ATT}$ & & $\begin{array}{l}\text { Virulence of the mutant } \\
\text { rescued by } \mathrm{FeCl}_{3} \text { injection }\end{array}$ & & [96] \\
\hline & YfeABCD & Divalent cation transporter & $\mathrm{I}: \mathrm{ATT}$ & & $\begin{array}{l}\text { Virulence of the mutant } \\
\text { rescued by } \mathrm{FeCl}_{3} \text { injection }\end{array}$ & & [96] \\
\hline \multicolumn{8}{|c|}{ Antimicrobial molecules } \\
\hline Photorhabdus & Hydroxy-stilbene & $\begin{array}{l}\text { Antimicrobial molecule whose } \\
\text { production is phenylalanine } \\
\text { ammonia-lyase (StIA) and polyketide } \\
\text { synthetase-dependant }\end{array}$ & $\begin{array}{l}\text { I: ATT } \\
\text { (sltA mutant) }\end{array}$ & & $\begin{array}{l}\text { Inhibition of phenoloxidase } \\
\text { activation }\end{array}$ & $\begin{array}{l}\text { Antibiotic activity } \\
\text { against Gram negative } \\
\text { and positive bacteria }\end{array}$ & [55] \\
\hline
\end{tabular}

Induces apoptosis of insect

Hemolytic activity in low-iron

(Photorhabdus) or

activities on insect

Late expression

$0 \bullet, 38]$

Specifically expressed

Specifically expressed in

Involved in iron acquisition from I: ATT

heme and ferritin

Iron dicitrate uptake

O: ATT

O: ATT

hemocoel, iron regulated

ion of

hagocytosis by

PP triggers the release of

cell membrane

of phagocytosis

Virulence of the mutan

Virulence of the mutant

Inhibition of phenoloxidase

ram negative

ammonia-lyase (StIA) and polyketide

(sltA mutant)

and positive bacteri 


\begin{tabular}{|c|c|c|c|c|c|c|c|}
\hline \multirow[t]{2}{*}{ Xenorhabdus } & Benzylidene-acetone & \multicolumn{3}{|l|}{ Monoterpenoid compound } & \multirow{2}{*}{$\begin{array}{l}\text { PP inactivates phenoloxidase } \\
\text { and phospholipase A2 }\end{array}$} & Antimicrobial molecule & [56] \\
\hline & Xenorhabdicin & \multicolumn{3}{|l|}{$\begin{array}{l}\text { Phage-tail bacteriocin encoded by } \\
\text { a P2-like tail synthesis gene cluster }\end{array}$} & & $\begin{array}{l}\text { Protects the nematode } \\
\text { against Gram negative } \\
\text { competitors }\end{array}$ & {$\left[54^{\circ}\right]$} \\
\hline \multicolumn{8}{|c|}{ Enzymes involved in envelop modification and membrane proteins } \\
\hline \multirow[t]{3}{*}{ B. thuringiensis } & Dlt ABCD & $\begin{array}{l}\text { Proteins required for the D-alanylation } \\
\text { of lipoteichoic acids (confers } \\
\text { positive charge) }\end{array}$ & $\begin{array}{l}\text { I: NON-VIR } \\
\text { O: ATT }\end{array}$ & & \multicolumn{2}{|l|}{ Resistance to AMPs } & {$\left[27^{\circ}\right]$} \\
\hline & CwpFM & Cell Wall peptidase & I: NON-VIR & $\begin{array}{l}\text { Adhesion to epithelial cells, } \\
\text { biofilm formation }\end{array}$ & \multicolumn{2}{|l|}{ Macrophage vacuolization } & [41] \\
\hline & FlhA & $\begin{array}{l}\text { Basal component of the flagella } \\
\text { apparatus }\end{array}$ & $\begin{array}{l}\text { O: ATT } \\
\text { I: ATT }\end{array}$ & $\begin{array}{l}\text { Allows motility and } \\
\text { adhesion to intestinal } \\
\text { cells }\end{array}$ & \multicolumn{2}{|l|}{$\begin{array}{l}\text { Inhibits production of } \\
\text { Phospholipase/hemolysins }\end{array}$} & [43] \\
\hline Photorhabdus & PbgP1P2P3P3E1E3E3 & $\begin{array}{l}\text { Responsible for the biosynthesis } \\
\text { of } L \text {-aminoarabinose and its } \\
\text { ligation onto the lipid A moiety } \\
\text { of LPS }\end{array}$ & I: ATT & & \multicolumn{2}{|l|}{ Resistance to AMPs } & [26] \\
\hline \multicolumn{8}{|c|}{ Extra-cellular enzymes } \\
\hline \multirow[t]{6}{*}{ B. thuringiensis } & InhA1 & Metalloprotease & $\begin{array}{l}\text { I: ATT } \\
\text { O: VIR }\end{array}$ & & \multirow{2}{*}{\multicolumn{2}{|c|}{$\begin{array}{l}\text { Resistance to AMP, allows } \\
\text { bacterial escape from } \\
\text { macrophages } \\
\text { Resistance to AMP }\end{array}$}} & {$[31,42]$} \\
\hline & InhA2 & Metalloprotease & $\begin{array}{l}\text { I: ATT } \\
\text { O: ATT }\end{array}$ & $\begin{array}{l}\text { Early phase of infection, } \\
\text { PlcR regulated }\end{array}$ & & & [97] \\
\hline & InhA3 & Metalloprotease & I: VIR & & \multirow{2}{*}{$\begin{array}{l}\text { Belongs to the NprR regulon } \\
\text { NprR regulon, degrades host } \\
\text { tissue components }\end{array}$} & \multirow{3}{*}{$\begin{array}{l}\text { Potentially involved } \\
\text { in nutriment acquisition }\end{array}$} & {$\left[49^{\bullet}, 98\right]$} \\
\hline & NprA & Metalloprotease & $\begin{array}{l}\text { I: VIR } \\
\text { O: VIR }\end{array}$ & & & & $\begin{array}{l}{\left[49^{\circ \bullet}\right]} \\
{[48]} \\
{[99]}\end{array}$ \\
\hline & Clp & $\begin{array}{l}\text { Proteases ClpP1 } \\
\text { (Intracellular ATP-protease } \\
\text { activity) }\end{array}$ & I: ATT & & $\begin{array}{l}\text { Implicated in stress resistance } \\
\text { and growth at low temperature }\end{array}$ & & [100] \\
\hline & MpbE & Enhancine & O: ATT & Expressed in the gut & & & {$[101,21]$} \\
\hline \multirow[t]{3}{*}{ Photorhabdus } & PrtA & Serralysin-like metalloprotease & & & $\begin{array}{l}\text { Degradation of AMPs by } \\
\text { the PP }\end{array}$ & \multirow[t]{3}{*}{$\begin{array}{l}\text { Localization in } \\
\text { conjunctive tissue } \\
\text { in dead insect }\end{array}$} & {$\left[11^{\bullet}, 32,102\right]$} \\
\hline & PrtS & M4 metalloprotease & & & $\begin{array}{l}\text { Induction of melanization } \\
\text { reaction by the PP }\end{array}$ & & [103] \\
\hline & SodA & Superoxide dismutase & I: ATT & & Resistance to oxidative stress & & [76] \\
\hline
\end{tabular}


[45*^]. The regulation of the hlyII hemolysin gene mentioned above might involve the ferric uptake repressor, Fur [46]. HlyII induces lysis of cells known to sequester iron during infection, and may thus participate in the release of iron. Furthermore, it was proposed that iron might constitute a signal to bacteria for the transition between the living insect infection and the cadaveric stage. Indeed, Jubelin et al. [10] found that expression of $x h b F$, a $X$. nematophila siderophore-related gene, was strongly upregulated in the early stages of infected larvae and downregulated in moribund larvae. The monitoring of virulence gene expression during insect infection process also revealed that $x a x A B$ and $x h l B A$ hemolysin genes are expressed concomitantly with the increase in iron availability detected at the time of insect death suggesting that iron constitutes a signal governing $X$. nematophila adaptation to shifting host environments.

\section{In the cadaver \\ Degradation of the host tissues}

In addition to the PlcR-regulated proteins, B. thuringiensis strains produce several chitinases [47], which might be involved in degradation of the chitin rich peritrophic matrix and parts of cuticle. The recently described quorum sensor NprR activates the transcription of a gene encoding an extracellular protease, NprA, which is the main extracellular component during sporulation (in vitro) [48]. The massive production of this neutral protease might provide nutrients allowing the bacterial population to achieve a complete sporulation, which takes place during the late stage of the infection in the insect cadaver. Moreover, it was shown that NprR controls the expression of several genes encoding chitinases. These enzymes and a lipopeptide also regulated by NprR, contribute to the development of $B$. thuringiensis during the late stage of infection promoting the saprophytic lifestyle of $B$. thuringiensis $\left[49^{\bullet \bullet}\right]$. Likewise, the metalloprotease InhA1 is produced during stationary phase [50] and may then contribute to the degradation of host tissue. Xenorhabdus and Photorhabdus also secrete several proteins such as proteases, lipases, hemolysins and chitinases that may participate in the transformation of the insect cadaver into nutrients $\left[30^{\bullet \bullet}, 51\right]$. Immuno-histochemistry revealed that on the basal side of the gut (facing the hemocoel), P. luminescens abundantly secretes two virulence factors, the gut-active toxin complex A (Tca) and the metalloprotease, PrtA, which may facilitate the rapid destruction of the gut tissue. Moreover, PrtA is detectable in the late step of septicemia when the insect is already dead $\left[11^{\circ}\right]$ and may consequently participate in the digestion of host components. By contrast, a recent study shows that an ortholog of Photorhabdus PrtA peptidase is produced by Xenorhabdus in the early stage of infection in Galleria mellonella [52].

Elimination of competitors and emergence from the cadaver The current view is that, in the insect cadaver, the numerous antimicrobial molecules (bacteriocins, secondary metabolites) produced by Xenorhabdus and Photorhabdus eliminate bacteria that might antagonize the growth of the nematode partner and compete for nutrient resources [53]. This was actually demonstrated for the phage-tail like bacteriocin of $X$. nematophila that is required for protecting the nematode partner, Steinernema carpocapsae, against bacterial competitors in G. mellonella [54 $4^{\circ}$. Interestingly, among those antimicrobial molecules, the hydroxy-stilbene, produced by $P$. luminescens, and the benzylideneacetone, produced by $X$. nematophila, have a dual function both as inhibitors of the phenoloxidase activity and as antimicrobials against microbial competitors in the insect cadaver $[55,56]$. Chitinases of Xenorhabdus and Photorhabdus may also be required at the late stage of infection in the cadaver to inhibit fungi invaders [57]. Likewise, a number of antimicrobial products including the PlcR-regulated peptides Spp may play a role both in the gut environment and in the cadaver to compete against invaders and commensal organisms. This also suggests that some PlcR-regulated factors might be functional at various steps during the $B$. thuringiensis lifecycle. It has been demonstrated that a NprR-dependent lipopeptide is essential to ensure the survival of $B$. thuringiensis in the insect cadaver $\left[4^{\bullet \bullet}\right]$. However, the precise role of this molecule remains to be elucidated. The NprR-regulated chitinases could also contribute to the degradation of the insect cadaver exoskeleton and to the dispersion of $B$. thuringiensis spores and crystals in the environment [58].

\section{Future challenges}

Over the past, the field of insect-microbes interaction has made spectacular progress revealing the sophisticated dialogue between bacterial pathogens and the infected host cells. Insects provide powerful infection models to identify virulence and adaptation factors and toxins from pathogenic bacteria $\left[12^{\bullet \bullet}, 59\right]$. Here we show that three entomopathogenic bacteria share common effectors although parts of their infection strategies are different (Table 1 and Figure 1). Some factors contribute to pathogenesis at several infection sites and stages, suggesting both a local adaptation and different regulatory mechanisms of these effectors. Notably, the role of pore-forming hemolysins and metalloproteases are crucial elements, as also recently reported for another entomopathogenic bacteria, Pseudomonas entomophila [60]. Today, the challenge is to study the properties of bacteria in the dynamic context of their interaction with host throughout the infection process. We believe that these insect models can be used to study various cutting edge aspects like coinfections, notably the interplay with commensal flora and other pathogens. Furthermore, insects provide an experimentally tractable organism and intra-vital imaging techniques enable the temporal and spatial visualization of events occurring within the full complexity of the living hosts. Meanwhile, to reach a real level of pathogen-insect dialogue, genetics tools and genome 
sequencing of the lepidopteran infection models (Spodoptera littoralis, Galleria mellonella, Manduca sexta) are needed. To increase the understanding of the infectious cycle at the tissue level, it is tempting to propose that these bacteria and the caterpillar host are further tools in 'tissue microbiology' [61 $\left.{ }^{\circ}\right]$. Indeed, by the association of several molecular, cellular, histo-pathological and imaging approaches, these small animals permit to visualize various tissue barriers on the same histological sample section. In addition, as several factors essential for tissue degradation and host cell death are similar to mammal pathogen effectors (pore-forming toxins and immune evasion compounds), the study of the bacteria-insect interactions is possibly a powerful approach to provide new valuable insights into factors and mechanisms involved in human pathogenesis.

\section{Acknowledgements}

Thanks to INRA departments MICA and SPE for financial support; and to former and actual group members as well as to the many colleagues whose work is contributing to the exciting area of science highlighted in this review.

\section{References and recommended reading}

Papers of particular interest, published within the period of review, have been highlighted as:

- of special interest

•• of outstanding interest

1. Vallet-Gely I, Lemaitre B, Boccard F: Bacterial strategies to - overcome insect defences. Nat Rev Microbiol 2008 , 6:302-313.

A nice overview of bacterial insect pathogens with issues to future studies and that highlights especially results from studies involving Drosophila immune responses to a few infective bacteria of this insect.

2. Jurat-Fuentes $\mathrm{J}$, Jackson $\mathrm{T}$ : Bacterial entomopathogens. In

- Insect Pathology, edn Second. Edited by Vega F, Kaya H.2012: Elsevier; 2012:266-349.

This new review (book chapter, most parts have free Web access) gives a real good update to the best studied bacterial insect pathogens, including the three highlighted in this review. Especially the mode of action of $B$. thuringiensis Cry toxins are nicely illustrated.

3. Bravo A, Likitvivatanavong S, Gill SS, Soberon M: Bacillus thuringiensis: a story of a successful bioinsecticide. Insect Biochem Mol Biol 2011, 41:423-431.

4. Sanchis V: From microbial sprays to insect-resistant transgenic plants: history of the biospesticide Bacillus thuringiensis. A review. Agron Sustain Dev 2011, 31:217-231.

5. Kolstø AB, Tourasse NJ, Økstad OA: What sets Bacillus anthracis apart from other Bacillus species? Annu Rev Microbiol 2009, 63:451-476.

6. Ehlers RU: Mass production of entomopathogenic nematodes for plant protection. Appl Microbiol Biotechnol 2001, 56:623-633.

7. Bravo A, Gill SS, Soberon M: Mode of action of Bacillus thuringiensis Cry and Cyt toxins and their potential for insect control. Toxicon 2007, 49:423-435.

8. Ffrench-Constant RH, Dowling A, Waterfield NR: Insecticidal toxins from Photorhabdus bacteria and their potential use in agriculture. Toxicon 2007, 49:436-451.

9. Vodovar N, Acosta C, Lemaitre B, Boccard F: Drosophila: a polyvalent model to decipher host-pathogen interactions. Trends Microbiol 2004, 12:235-242.

10. Jubelin G, Pagès S, Lanois A, Boyer M-H, Gaudriault S, Ferdy J-B,

-. Givaudan A: Studies of the dynamic expression of the
Xenorhabdus FliAZ regulon reveal atypical iron-dependent regulation of the flagellin and haemolysin genes during insect infection. Environ Microbiol 2011, 13:1271-1284.

This is the first study investigating the dynamics of virulence gene expression during insect infection and nematode association by carrying out real-time expression analysis using an unstable GFP. These findings shed further light on the role of the flagellar regulon in the Xenorhabdus life cycle and on the role of iron as a signal governing bacterial adaptation to shifting host environments.

11. Silva CP, Waterfield NR, Daborn PJ, Dean P, Chilver T, Au CPY,

- Sharma S, Potter U, Reynolds SE, Ffrench-Constant RH: Bacterial infection of a model insect: Photorhabdus luminescens and Manduca sexta. Cell Microbiol 2002, 4:329-339.

For the first time, this study shows the specific location of Photorhabdus luminescens between the extracellular matrix and basal membrane of the midgut epithelium during infection of Manduca sexta. Bacterial expression of the gut-active Toxin complex A (Tca) and the RTX-like metalloprotease (PrtA) in this gut niche is also documented.

12. Fedhila S, Daou N, Lereclus D, Nielsen-LeRoux C: Identification

-. of Bacillus cereus internalin and other candidate virulence genes specifically induced during oral infection in insects. Mol Microbiol 2006, 62:339-355.

Describes a succesfull use of a positive promoter trap system (IVET) for indentification of genes expressed during the infection process in Galleria melonella larvae.

13. Heimpel A, Angus TJIP: The site of action of crystalliferous bacteria in lepidotera larvae. J Insect Pathol 1959, 1:52-170.

14. Cherif A, Rezgui W, Raddadi N, Daffonchio D, Boudabous A: Characterization and partial purification of entomocin 110, a newly identified bacteriocin from Bacillus thuringiensis subsp. Entomocidus HD110. Microbiol Res 2008, 163:684-692.

15. Jarosz J: Gut flora of Galleria mellonella suppressing ingested bacteria. J Invertebr Pathol 1979, 34:192-198.

16. Salamitou $S$, Ramisse F, Brehélin M, Bourguet D, Gilois N, Gominet M, Hernandez E, Lereclus D: The plcR regulon is involved in the opportunistic properties of Bacillus thuringiensis and Bacillus cereus in mice and insects. Microbiology 2000, 146:2825-2832.

17. Fedhila S, Gohar M, Slamti L, Nel P, Lereclus D: The Bacillus thuringiensis PIcR-regulated gene inhA2 is necessary, but not sufficient, for virulence. J Bacteriol 2003, 185:2820-2825.

18. Gohar M, Faegri K, Perchat S, Ravnum S, Økstad OA, Gominet M, Kolstø $A B$, Lereclus $D$ : The PIcR virulence regulon of Bacillus cereus. PLOS ONE 2008, 3:e2793.

19. Klimowicz AK, Benson TA, Handelsman J: A quadrupleenterotoxin-deficient mutant of Bacillus thuringiensis remains insecticidal. Microbiology 2010, 156:3575-3583.

20. Kyei-Poku G, Gauthier D, Pang A, van Frankenhuyzen K: Detection of Bacillus cereus virulence factors in commercial products of Bacillus thuringiensis and expression of diarrheal enterotoxins in a target insect. Can J Microbiol 2007, 53:1283-1290.

21. Fang S, Wang L, Guo W, Zhang X, Peng D, Luo C, Yu Z, Sun M: Bacillus thuringiensis Bel protein enhances the toxicity of Cry1Ac protein to Helicoverpa armigera larvae by degrading insect intestinal mucin. Appl Environ Microbiol 2009, 75:5237-5243.

22. Nappi AJ, Ottaviani E: Cytotoxicity and cytotoxic molecules in invertebrates. Bioessays 2000, 22:469-480.

23. Gunn JS, Belden WJ, Miller SI: Identification of PhoP-PhoQ activated genes within a duplicated region of the Salmonella typhimurium chromosome. Microb Pathog 1998, 25:77-90.

24. Guo L, Lim KB, Gunn JS, Bainbridge B, Darveau RP, Hackett M, Miller SI: Regulation of lipid A modifications by Salmonella typhimurium virulence genes phoP-phoQ. Science 1997, 276:250-253.

25. Derzelle S, Turlin E, Duchaud E, Pages S, Kunst F, Givaudan A, Danchin A: The PhoP-PhoQ two-component regulatory system of Photorhabdus luminescens is essential for virulence in insects. $J$ Bacteriol 2004, 186:1270-1279. 
10 Ecology

26. Bennett HPJ, Clarke DJ: The pbgPE operon in Photorhabdus luminescens is required for pathogenicity and symbiosis. $J$ Bacteriol 2005, 187:77-84.

27. Abi Khattar Z, Rejasse A, Destoumieux-Garzón D, Escoubas J,

- Sanchis V, Lereclus D, Givaudan A, Kallassy M, Nielsen-Leroux C, Gaudriault S: The dlt operon of Bacillus cereus is required for resistance to cationic antimicrobial peptides and virulence in insects. J Bacteriol 2009, 191:7063-7073.

This study demonstrated that the dlt mutant of Bacillus cereus has a attenuated phenotype when injected into the hemocoel of Galleria mellonella and Spodoptera littoralis. It is also the first report of the presence of a dlt-like locus in Gram-negative bacteria including Photorhabdus luminescens.

28. Ji D, Kim Y: An entomopathogenic bacterium, Xenorhabdus nematophila, inhibits the expression of an antibacterial peptide, cecropin, of the beet armyworm, Spodoptera exigua. J Insect Physiol 2004, 50:489-496.

29. Park Y, Herbert EE, Cowles CE, Cowles KN, Menard ML Orchard SS, Goodrich-Blair H: Clonal variation in Xenorhabdus nematophila virulence and suppression of Manduca sexta immunity. Cell Microbiol 2007, 9:645-656.

30. Richards GR, Goodrich-Blair H: Masters of conquest and

-. pillage: Xenorhabdus nematophila global regulators control transitions from virulence to nutrient acquisition. Cell Microbiol 2009, 11:1025-1033.

This review emphasizes regulatory cascades involved in coordinating transitions between various stages of the $X$. nematophila life cycle: infection, reproduction and transmission.

31. Dalhammar G, Steiner $\mathrm{H}$ : Characterization of inhibitor $\mathbf{A}$, a protease from Bacillus thuringiensis which degrades attacins and cecropins, two classes of antibacterial proteins in insects. Eur J Biochem 1984, 139:247-252.

32. Cabral CM, Cherqui A, Pereira A, Simões N: Purification and characterization of two distinct metalloproteases secreted by the entomopathogenic bacterium Photorhabdus sp. strain Az29. Appl Environ Microbiol 2004, 70:3831-3838.

33. Brugirard-Ricaud K, Duchaud E, Givaudan A, Girard PA, Kunst F, Boemare N, Brehélin M, Zumbihl R: Site-specific antiphagocytic function of the Photorhabdus luminescens type III secretion system during insect colonization. Cell Microbiol 2005, 7:363-371.

34. Chaston JM, Suen G, Tucker SL, Andersen AW, Bhasin A, Bode E, Bode HB, Brachmann AO, Cowles CE, Cowles KN et al.: The entomopathogenic bacterial endosymbionts Xenorhabdus and Photorhabdus: convergent lifestyles from divergent genomes. PLOS ONE 2011, 6:e27909.

35. Park D, Forst S: Co-regulation of motility, exoenzyme and antibiotic production by the EnvZ-OmpR-FlhDC-FliA pathway in Xenorhabdus nematophila. Mol Microbiol 2006, 61:1397-1412.

36. Lanois A, Jubelin G, Givaudan A: FliZ, a flagellar regulator, is at the crossroads between motility, haemolysin expression and virulence in the insect pathogenic bacterium Xenorhabdus. Mol Microbiol 2008, 68:516-533.

37. Richards GR, Herbert EE, Park Y, Goodrich-Blair H: Xenorhabdus nematophila IrhA is necessary for motility, lipase activity, toxin expression, and virulence in Manduca sexta insects. $J$ Bacteriol 2008, 190:4870-4879.

38. Vigneux F, Zumbihl R, Jubelin G, Ribeiro C, Poncet J, Baghdiguian $S$, Givaudan A, Brehélin M: The xaxAB genes encoding a new apoptotic toxin from the insect pathogen Xenorhabdus nematophila are present in plant and human pathogens. J Biol Chem 2007, 282:9571-9580.

39. Cowles KN, Goodrich-Blair H: Expression and activity of a Xenorhabdus nematophila haemolysin required for full virulence towards Manduca sexta insects. Cell Microbiol 2005, 7:209-219.

40. Tran SL, Guillemet E, Ngo-Camus M, Clybouw C, Puhar A, Moris A, Gohar M, Lereclus D, Ramarao N: Haemolysin II is a Bacillus cereus virulence factor that induces apoptosis of macrophages. Cell Microbiol 2011, 13:92-108.
41. Tran SL, Guillemet E, Gohar M, Lereclus D, Ramarao N: CwpFM (EntFM) is a Bacillus cereus potential cell wall peptidase implicated in adhesion, biofilm formation, and virulence. $J$ Bacteriol 2010, 192:2638-2642.

42. Ramarao N, Lereclus D: The InhA1 metalloprotease allows spores of the $B$. cereus group to escape macrophages. Cell Microbiol 2005, 7:1357-1364.

43. Bouillaut L, Ramarao N, Buisson C, Gilois N, Gohar M, Lereclus D, Nielsen-Leroux C: FIhA influences Bacillus thuringiensis PIcRregulated gene transcription, protein production, and virulence. Appl Environ Microbiol 2005, 71:8903-8910.

44. Cherayil BJ: The role of iron in the immune response to bacterial infection. Immunol Res 2011, 50:1-9.

45. Daou N, Buisson C, Gohar M, Vidic J, Bierne H, Kallassy M,

- Lereclus D, Nielsen-LeRoux C: IlsA, a unique surface protein of Bacillus cereus required for iron acquisition from heme, hemoglobin and ferritin. PLoS Pathog 2009, 5:e1000675.

This study shows a visual in vivo localized expression, using GFP promoter fusion, of a factor responding to iron depleted environment of the insect hemocoel. It also highlights for the first time the interaction of a bacterial surface protein and host ferritin.

46. Harvie DR, Vilchez S, Steggles JR, Ellar DJ: Bacillus cereus Fur regulates iron metabolism and is required for full virulence. Microbiology 2005, 151:569-577.

47. Liu D, Chen Y, Cai J, Xiao L, Liu C: Chitinase B from Bacillus thuringiensis enhancing potential and its antagonism and insecticidal. Wei Sheng Wu Xue Bao 2009, 49:180-185.

48. Perchat S, Dubois T, Zouhir S, Gominet M, Poncet S, Lemy C, Aumont-Nicaise M, Deutscher J, Gohar M, Nessler S et al.: A cellcell communication system regulates protease production during sporulation in bacteria of the Bacillus cereus group. Mol Microbiol 2011, 82:619-633.

49. Dubois T, Faegri K, Perchat S, Lemy C, Buisson C, Nielsen-

-. LeRoux C, Gohar M, Ramarao N, Kolstø A, Lereclus D: Necrotrophism is a quorum-sensing-regulated lifestyle in Bacillus thuringiensis. PloS Pathog 2012, 4:e1002629.

This article highlights that the pathogenic and necrotrophic lifestyles of $B$. thuringiensis occur successively during the infectious cycle. It shows that the quorum sensor NprR triggers the production of a lipopeptide allowing $B$. thuringiensis to survive and eventually sporulate in the host cadaver

50. Grandvalet C, Gominet M, Lereclus D: Identification of genes involved in the activation of the Bacillus thuringiensis inhA metalloprotease gene at the onset of sporulation. Microbiology 2001, 147:1805-1813.

51. Forst S, Dowds B, Boemare N, Stackebrandt E: Xenorhabdus and Photorhabdus spp.: bugs that kill bugs. Annu Rev Microbiol 1997, 51:47-72.

52. Massaoud M, Marokházi J, Fodor A, Venekei I: Proteolytic enzyme production by strains of the insect pathogen xenorhabdus and characterization of an early-log-phasesecreted protease as a potential virulence factor. Appl Environ Microbiol 2010, 76:6901-6909.

53. Bode HB: Entomopathogenic bacteria as a source of secondary metabolites. Curr Opin Chem Biol 2009, 13:224-230.

54. Morales-Soto N, Forst SA: The xnp1 P2-like tail synthesis gene

- cluster encodes Xenorhabdicin and is required for interspecies competition. J Bacteriol 2011, 193:3624-3632.

The R-type bacteriocin (xenorhabdicin) is shown to be produced in the hemocoel of insects infected with Xenorhabdus nematophila. Xenorhabdicin was required for killing the potential competitor Photorhabdus luminescens and protecting the nematode partner.

55. Eleftherianos I, Boundy S, Joyce SA, Aslam S, Marshall JW, Cox RJ, Simpson TJ, Clarke DJ, Ffrench-Constant RH, Reynolds SE: An antibiotic produced by an insect-pathogenic bacterium suppresses host defenses through phenoloxidase inhibition. Proc Natl Acad Sci USA 2007, 104:2419-2424.

56. Song C, Seo S, Shrestha S, Kim Y: Bacterial metabolites of an entomopathogenic bacterium, Xenorhabdus nematophila, inhibit a catalytic activity of Phenoloxidase of the diamondback moth, Plutella xylostella. J Microbiol Biotechnol 2011, 21:317-322. 
57. Chen G, Zhang Y, Li J, Dunphy GB, Punja ZK, Webster JM: Chitinase activity of Xenorhabdus and Photorhabdus species, bacterial associates of entomopathogenic nematodes. $J$ Invertebr Pathol 1996, 68:101-108.

58. Raymond B, Johnston PR, Nielsen-LeRoux C, Lereclus D, Crickmore $\mathrm{N}$ : Bacillus thuringiensis: an impotent pathogen? Trends Microbiol 2010, 18:189-194.

59. Tan MW: Cross-species infections and their analysis. Annu Rev Microbiol 2002, 56:539-565.

60. Opota O, Vallet-Gely I, Vincentelli R, Kellenberger C, lacovache I, Gonzalez MR, Roussel A, van der Goot FG, Lemaitre B: Monalysin, a novel ss-pore-forming toxin from the Drosophila pathogen Pseudomonas entomophila, contributes to host intestinal damage and lethality. PLoS Pathog 2011, 7:e1002259.

61. Richter-Dahlfors A, Rhen M, Udekwu K: Tissue microbiology

- provides a coherent picture of infection. Curr Opin Microbiol 2012, 15:15-22.

This review is not concerned with insect pathogens but highlights the new concept of 'tissue microbiology' covering several approaches needed to get an overall understanding of an infection process.

62. Castillo JC, Reynolds SE, Eleftherianos I: Insect immune responses to nematode parasites. Trends Parasitol 2011, 27:537-547.

63. Goodrich-Blair $\mathrm{H}$, Clarke DJ: Mutualism and pathogenesis in Xenorhabdus and Photorhabdus: two roads to the same destination. Mol Microbiol 2007, 64:260-268.

64. Hegedus D, Erlandson M, Gillott C, Toprak U: New insights into peritrophic matrix synthesis, architecture, and function. Annu Rev Entomol 2009, 54:285-302.

65. Jiang $\mathrm{H}$, Vilcinskas $\mathrm{A}$, Kanost MR: Immunity in lepidopteran insects. Adv Exp Med Biol 2010, 708:181-204.

66. van Frankenhuyzen K: Insecticidal activity of bacillus thuringiensis crystal proteins. J Invertebr Pathol 2009, 101:1-16.

67. Soberon M, Gill SS, Bravo A: Signaling versus punching hole: how do Bacillus thuringiensis toxins kill insect midgut cells? Cell Mol Life Sci 2009, 66:1337-1349.

68. Rees J, Jarett P, Ellar D: Peritrophic membrane contribute to bt Cry delta-endotoxion susceptibility in Lepidoptera and the effect of Calcofluor. J Invertebr Pathol 2009, 100:139-146.

69. Mason KL Stepien TA, Blum JE, Holt JF, Labbe NH, Rush JS, Raffa KF, Handelsman J: From commensal to pathogen: translocation of Enterococcus faecalis from the midgut to the hemocoel of Manduca sexta. MBio 2011, 2 e00065-00011.

70. Li RS, Jarrett P, Burges HD: Importance of spores, crystals, and $\partial$-endotoxins in the pathogenicity of different varieties of Bacillus thuringiensis in Galleria mellonela and Pieris brassicae. J Invertebr Pathol 1987, 50:277-284.

71. Lang AE, Schmidt G, Schlosser A, Hey TD, Larrinua IM, Sheets JJ, Mannherz HG, Aktories K: Photorhabdus luminescens toxins ADP-ribosylate actin and RhoA to force actin clustering. Science 2010, 327:1139-1142.

72. Joshi MC, Sharma A, Kant S, Birah A, Gupta GP, Khan SR, Bhatnagar R, Banerjee N: An insecticidal GroEL protein with chitin binding activity from Xenorhabdus nematophila. J Biol Chem 2008, 283:28287-28296.

73. Busby JN, Landsberg MJ, Simpson RM, Jones SA, Hankamer B Hurst MRH, Lott JS: Structural analysis of Chi1 chitinase fromYen-Tc: the multisubunit insecticidal $A B C$ toxin complex of Yersinia entomophaga. J Mol Biol 2012, 415:359-371.

74. Blackburn MB, Martin PAW, Kuhar D, Farrar RR, GundersenRindal DE: The occurrence of Photorhabdus-like toxin complexes in Bacillus thuringiensis. PLOS ONE 2011, 6:e18122.

75. Krin E, Chakroun N, Turlin E, Givaudan A, Gaboriau F, Bonne I, Rousselle J-C, Frangeul L, Lacroix C, Hullo M-F et al.: Pleiotropic role of quorum-sensing autoinducer 2 in Photorhabdus luminescens. Appl Environ Microbiol 2006, 72:6439-6451.

76. Chalabaev $S$, Turlin $E$, Charles J-F, Namane A, Pagès $S$, Givaudan A, Brito-Fravallo E, Danchin A, Biville F: The HcaR regulatory protein of Photorhabdus luminescens affects the production of proteins involved in oxidative stress and toxemia. Proteomics 2007, 7:4499-4510.

77. Joyce SA, Clarke DJ: A hexA homologue from Photorhabdus regulates pathogenicity, symbiosis and phenotypic variation Mol Microbiol 2003, 47:1445-1457.

78. Givaudan A, Lanois A: flhDC, the flagellar master operon of Xenorhabdus nematophilus: requirement for motility, lipolysis, extracellular hemolysis, and full virulence in insects. $J$ Bacteriol 2000, 182:107-115.

79. Cowles KN, Cowles CE, Richards GR, Martens EC, GoodrichBlair $\mathrm{H}$ : The global regulator Lrp contributes to mutualism, pathogenesis and phenotypic variation in the bacterium Xenorhabdus nematophila. Cell Microbiol 2007, 9:1311-1323.

80. Herbert Tran EE, Goodrich-Blair H: CpxRA contributes to Xenorhabdus nematophila virulence through regulation of IrhA and modulation of insect immunity. Appl Environ Microbiol 2009, 75:3998-4006.

81. Donovan WP, Donovan JC, Engleman JT: Gene knockout demonstrates that vip3A contributes to the pathogenesis of Bacillus thuringiensis toward Agrotis ipsilon and Spodoptera exigua. J Invertebr Pathol 2001, 78:45-51.

82. Bowen D, Rocheleau TA, Blackburn M, Andreev O, Golubeva E, Bhartia R, ffrench-Constant RH: Insecticidal toxins from the bacterium Photorhabdus luminescens. Science 1998 280:2129-2132.

83. Blackburn M, Golubeva E, Bowen D, Ffrench-Constant R: A novel insecticidal toxin from photorhabdus luminescens, toxin complex a (Tca), and its histopathological effects on the midgut of manduca sexta. Appl Environ Microbiol 1998, 64:3036-3041.

84. Morgan J, Sergeant M, Ellis D, Ousley M, Jarrett P: Sequence analysis of insecticidal genes from Xenorhabdus nematophilus PMFI296. Appl Environ Microbiol 2001, 67:2062-2069.

85. Duchaud E, Rusniok C, Frangeul L, Buchrieser C, Givaudan A, Taourit S, Bocs S, Boursaux-Eude C, Chandler M, Charles J-F et al:: The genome sequence of the entomopathogenic bacterium Photorhabdus luminescens. Nat Biotechnol 2003, 21:1307-1313

86. Waterfield N, Kamita SG, Hammock BD, Ffrench-Constant R: The Photorhabdus Pir toxins are similar to a developmentally regulated insect protein but show no juvenile hormone esterase activity. FEMS Microbiol Lett 2005, 245:47-52.

87. Li M, Wu G, Liu C, Chen Y, Qiu L, Pang Y: Expression and activity of a probable toxin from Photorhabdus luminescens. Mol Biol Rep 2009, 36:785-790.

88. Khandelwal P, Choudhury D, Birah A, Reddy MK, Gupta GP Banerjee N: Insecticidal pilin subunit from the insect pathogen Xenorhabdus nematophila. J Bacteriol 2004, 186:6465-6476.

89. Stenfors Arnesen LP, Fagerlund A, Granum PE: From soil to gut: Bacillus cereus and its food poisoning toxins. FEMS Microbiol Rev 2008, 32:579-606.

90. Cadot C, Tran SL, Vignaud ML, De Buyser ML, Kolsto AB, Brisabois A, Nguyen-The C, Lereclus D, Guinebretiere MH, Ramarao N: InhA1, NprA and Hlyll as candidates to differentiate pathogenic from non-pathogenic Bacillus cereus strains. J Clin Microbiol 2010, 48:1358-1365.

91. Brillard J, Duchaud E, Boemare N, Kunst F, Givaudan A: The PhIA hemolysin from the entomopathogenic bacterium Photorhabdus luminescens belongs to the two-partne secretion family of hemolysins. J Bacteriol 2002, 184:38713878.

92. Harvie DR, Ellar DJ: A ferric dicitrate uptake system is required for the full virulence of Bacillus cereus. Curr Microbiol 2005, 50:246-250.

93. Chavez CV, Jubelin G, Courties G, Gomard A, Ginibre N, Pages S, Taïeb F, Girard P-A, Oswald E, Givaudan A et al.: The cyclomodulin Cif of Photorhabdus luminescens inhibits insect 
cell proliferation and triggers host cell death by apoptosis. Microbes Infect 2010, 12:1208-1218.

94. Daborn PJ, Waterfield N, Silva CP, Au CPY, Sharma S, ffrenchConstant $\mathrm{RH}$ : A single Photorhabdus gene, makes caterpillars floppy (mcf), allows Escherichia coli to persist within and kill insects. Proc Natl Acad Sci USA 2002, 99:10742-10747.

95. Vlisidou I, Dowling AJ, Evans IR, Waterfield N, FfrenchConstant RH, Wood W, Schneider DS: Drosophila embryos as model systems for monitoring bacterial infection in real time. PLoS Pathog 2009, 5:e1000518.

96. Watson RJ, Millichap P, Joyce SA, Reynolds S, Clarke DJ: The role of iron uptake in pathogenicity and symbiosis in Photorhabdus luminescens TT01. BMC Microbiol 2010, 10:177.

97. Fedhila S, Nel P, Lereclus D: The InhA2 metalloprotease of Bacillus thuringiensis strain 407 is required for pathogenicity in insects infected via the oral route. J Bacteriol 2002, 184:3296-3304.

98. Guillemet E, Cadot C, Tran SL, Guinebretiere MH, Lereclus D, Ramarao N: The InhA metalloproteases of Bacillus cereus contribute concomitantly to virulence. J Bacteriol 2010, 192:286-294

99. Chung MC, Popova TG, Millis BA, Mukherjee DV, Zhou W Liotta LA, Petricoin EF, Chandhoke V, Bailey C, Popov SG: Secreted neutral metalloproteases of Bacillus anthracis as candidate pathogenic factors. $J$ Biol Chem 2006, 281:31408-31418.

100. Fedhila S, Msadek T, Nel P, Lereclus D: Distinct clpP genes control specific adaptive responses in Bacillus thuringiensis. $J$ Bacteriol 2002, 184:5554-5562.

101. Hajaij-Ellouze M, Fedhila S, Lereclus D, Nielsen-LeRoux C: The enhancin-like metalloprotease from the Bacillus cereus group is regulated by the pleiotropic transcriptional activator PIcR but is not essential for larvicidal activity. FEMS Microbiol Lett 2006, 260:9-16.

102. Bowen DJ, Rocheleau TA, Grutzmacher CK, Meslet L, Valens M Marble D, Dowling A, Ffrench-Constant R, Blight MA: Genetic and biochemical characterization of PrtA, an RTX-like metalloprotease from Photorhabdus. Microbiology (Reading, Engl) 2003, 149:1581-1591.

103. Held KG, LaRock CN, D'Argenio DA, Berg CA Collins CM: A metalloprotease secreted by the insect pathogen Photorhabdus luminescens induces melanization. Appl Environ Microbiol 2007, 73:7622-7628.

104. Song F, Peng Q, Brillard J, Buisson C, de Been M, Abee T, Broussolle V, Huan D, Zhann J, Lereclus D, Nielsen-LeRoux C: A multi component sugar phosphate sensor system specifically induced in Bacillus cereus during infection of the insect gut. FASEB $J$ 2012, in press 